\title{
NOLŪKA SATURS UN BŪTĪBA \\ KRIMINĀLTIESİBĀS (UZ KRIMINĀLLIKUMA \\ 195. PANTA REGULĒJUMA PAMATA)
}

\section{CONTENT AND SUBSTANCE OF PURPOSE IN CRIMINAL LAW (ON THE BASIS OF SECTION 195 OF CRIMINAL LAW)}

\section{Uldis Krastiņš, Dr. habil. iur.}

Latvijas Universitātes Juridiskās fakultātes

Krimināltiesisko zinātṇu katedras profesors

\section{Summary}

The article provides an analysis of the term "purpose of a criminal offence" in connection with the activities, specified in paragraph one of Section 5 of the Law on the Prevention of Money Laundering and Terrorism and Proliferation Financing, because they form the objective side of the criminal offence provided for in Section 195 of the Criminal Law.

The author proposes an idea that the requirement stipulated in paragraph one of Section 5 of the above law to establish that the "actions have been carried out for the purpose of concealing or disguising the illicit origin of funds" does not relate to the actual actions of laundering provided for in the same paragraph (the conversion of proceeds of crime into other valuables, change of their location or ownership).

Such a purpose should solely be applied to the activities that are directed to concealing or disguising the illicit origin of funds, and not to the activities legalizing the funds.

The author proposes to consider that the purpose of money laundering is to create the appearance (confidence) of the offence and the legality (lawfulness) of the funds used in it, to the persons unrelated to the criminal offence, if it is performed as described in paragraphs one and two of Section 5 of the abovementioned law.

Atslēgvārdi: Krimināllikums, noziedzīgi iegūtu līdzekḷu legalizācija, apzināšanās, nolūks, vaina

Keywords: Criminal Law, money laundering, awareness, purpose, guilt

\section{Ievads}

Raksta mērḳis ir analizēt personas psihiskās darbības izpausmes saistībā ar noziegumu, kas paredzēts Krimināllikuma (turpmāk arī KL) 195. pantāi un kas objektīvi izpaužas kā noziedzīgi iegūtu līdzekḷu legalizācija. Tie ir jautājumi

1 Krimināllikums. Par Krimināllikuma spēkā stāšanās un piemērošanas kārtību. 16. izd. Rīga: Tiesu namu ag̉entūra, 2018. 
par personas apzināšanos, ka legalizējamie līdzekḷi ir noziedzīgi iegūti, un par vainīgā nolūku turpmākā laikā, rìkojoties ar noziedzīgi iegūtajiem lìdzekḷiem. Uz noziedzīgu nodarījumu izdarījušās personas psihiskās darbības teorētiskās analīzes pamata un ievērojot konkrētā nozieguma normatīvā regulējuma nostādnes, raksta autors piedāvās savu viedokli par teorētiskiem un praktiskiem risinājumiem, kvalificējot noziedzīgos nodarījumus atbilstoši Krimināllikuma 195. pantam.

\section{Vainas psiholoğiskā koncepcija un nodarījuma subjektīvā puse}

Latvijas krimināltiesības tradicionāli balstās uz vainas psihologiskās koncepcijas pamatnostādnēm, ${ }^{2}$ kas normatīvi nostiprinātas Krimināllikuma 8. panta otrajā daḷā, kurā pateikts, ka, nosakot noziedzīgu nodarījumu izdarījušās personas vainas formu, jākonstatē šìs personas psihiskā tieksme pret noziedzīgā nodarījuma objektīvajām pazīmēm. Uz Krimināllikuma 8. panta otrajā daḷā nostiprinātās vainas psiholoǵiskās koncepcijas pamata teorētiski izstrādāta un praksē aprobēta mācība par vienu no obligātajiem noziedzīga nodarījuma sastāva elementiem - subjektivo pusi.

Noziedzīga nodarījuma subjektīvā puse ir noziedzīgo nodarījumu izdarījušās personas (nodarījuma subjekta) psihiskā darbība, kas tieši saistīta ar viṇas reāli izdarìto (nodarījuma objektīvās puses pazīmēm), un tā apvieno vienotā veselumā personas psihiskās darbības intelektuālos un gribas procesus virzībā uz noziedzīga nodarījuma izdarǐšanu. Noziedzīga nodarījuma subjektīvā puse atspoguḷo saistību starp personas apziņu un gribu un viņas izdarìto nodarījumu. ${ }^{3}$ Noziedzīga nodarījuma subjektīvā puse ir visciešākajā veidā saistīta ar vainas jēdzienu krimināltiesībās, kuras pazìmes nostiprinātas KL 9. un 10. pantā, formulejot divas vainas formas - nodomu un neuzmanību, kā arī to veidus tiešu un netiešu nodomu un attiecīgi - noziedzīgu nevērību un noziedzìgu pašpal̦āvību.

Iepriekšminētās nostādnes ir svarīgi atzīmēt tādā ziṇā, ka kriminālatbildības pamatnosacỉjumos (KL 1. panta pirmā daḷa) iekḷauta prasība konstatēt personas vainu noziedzīga nodarījuma izdarīšanā, lai būtu pamats viṇas saukšanai pie kriminālatbildības.

Rezumējot kopumā iepriekš minētās krimināltiesību normatīvās un teorētiskās nostādnes, varam teikt, ka ikvienā konkrētā gadījumā, risinot jautājumu par personas vainu viṇas izdarītajā nodarījumā, jāanalizē un jāpierāda tās psihiskā attieksme ne tikai pret konkrētā noziedzīgā nodarījuma pamatpazìmēm (darbību, bezdarbību un ar tām cēloṇsakarīgi saistītajām sekām, ja tās iekḷautas sastāva pazīmju skaitā, kā arī vainas formu un tās veidu), bet arī pret

2 Vairāk sk.: Krastinš̌ U. Vainas psihologiskā koncepcija. Grām.: Satversmē nostiprināto vērtību aizsardzība: dažādu tiesību nozaru perspektīva. Latvijas Universitātes 77. starptautiskās zinātniskās konferences rakstu krājums. Rīga: LU Akadēmiskais apgāds, 2019, 49.-57. lpp.

3 Krastiņš U., Liholaja V., Niedre A. Krimināltiesības. Vispārīgā daḷa. 3. papild. izd. Rīga: Tiesu namu aǵentūra, 2008, 154. lpp.; Krastiņš U., Liholaja V. Krimināllikuma komentāri. Pirmā daḷa (I-VIII² nodaḷa). 2. papild. izd. Rīga: Tiesu namu aǵentūra, 2018, 60. lpp. 
papildpazīmēm, piemēram, saistībā ar šì raksta tēmu - tādām noziedzīga nodarījuma sastāva subjektīvās puses pazīmēm kā nolūks, mērḳis, motīvs. ${ }^{4}$

\section{Krimināllikuma 195. pantā paredzētā nozieguma pazīmju normativais regulējums}

Krimināllikuma 195. pantā paredzētā nozieguma sastāvs pēc pazīmju apraksta ir vienkāršs, jo tajā nosaukts tikai šā nodarījuma priekšmets - noziedzīgi iegūti finanšu līdzekḷi vai cita manta - un noziedzīgās darbības apzīmējums - legalizēšana. Tajā pašā laikā šì panta dispozīcijas satura izpratne ir visai sarežg̀ita kā attiecībā uz nozieguma priekšmetu, tā uz noziedzīgo darbību, kā arī subjektīvās puses pazīmēm, jo šajā pantā paredzētā nozieguma objektīvo un subjektīvo pazìmju apraksts atrodams citā normativāa aktā un tieši to izpratne rada gan teorētiska, gan praktiska rakstura problēmas.

Tāds tiesību normatīvais akts nacionālā līmenī, balstoties uz starptautiskajos tiesību aktos nostiprinātajām atziṇām, ir Saeimas 2008. gada 17. jūlijā pieṇemtais likums - Noziedzīgi iegūtu līdzekḷu legalizācijas un terorisma un proliferācijas finansēšanas novēršanas likums (turpmāk arī Likums) 2019. gada 13. jūnija redakcijā. ${ }^{5}$ Šà likuma 5. panta pirmās daḷas trijos punktos norādìtas triju grupu faktiskās noziedzīgās darbības, kas raksturo noziedzīgi iegūtu lìdzekḷu legalizācijas objektīvo pusi: 1) noziedzīgi iegūtu līdzekḷu pārvēršana citās vērtībās, to atrašanās vietas vai piederības mainǐšana; 2) noziedzīgi iegūtu līdzekḷu patiesā rakstura, izcelsmes, atrašanās vietas, izvietojuma, kustības, piederības slēpšana vai maskēšana; 3) citas personas noziedzịgi iegūtu līdzekḷu iegūšana īpašumā, valdījumā vai lietojumā vai to realizēšana.

Daudz sarežg̀ìtāks ir Likumā reglamentētais noziedzīgi iegūtu līdzekḷu legalizācijas subjektīvās puses risinājums.

Šā likuma 5. panta pirmās daḷas 1. un 2. punktā minētās darbības attiecas uz personu, kura legalizē pašas noziedzīgi iegūtos līdzekḷus, bet 3. punktā minètās darbības saistāmas ar personu, kura legalizē citas personas noziedzīgi iegūtus līdzekḷus. Šis atšḳirīgais subjektu raksturojošais faktors ietekmē vainīgā subjektīvās attieksmes risinājumu, jo visas legalizācijas darbỉbas saistītas ar apzināšanos, ka līdzekl̦i, kas tiek legalizēti, ir iegūti noziedzīgi.

Gadijjumos, kad persona legalizē pašas noziedzīgi iegūtos līdzekḷus, pārsvarā gadījumu vainīgais ne tikai apzinās līdzekḷu noziedzīgo izcelsmi, bet nepārprotami par to zina.

Citādāka situācija rodas tādos gadījumos, kad legalizēti tiek citas personas noziedzīgi iegūti līdzekḷi, jo legalizētājs nav ieinteresēts atklāt patieso izpratni par to, kādā ceḷā viṇa rīcībā nonākušie lìdzekḷi ir tikuši iegūti (5. panta pirmās dalıs 3. punkts).

Iepriekšminētās situācijas risinājumu atvieglo Likumā izdarītais grozījums, ka personas psihiskā attieksme pret apstākli, ka legalizētie līdzekḷi ir noziedzīgi iegūti, var izpausties arī apzināta piẹ̦āvuma veidā. Šis nosacījums iekḷauts Likuma pirmajā prim pantā.

\footnotetext{
4 Vairāk par noziedzīga nodarījuma sastāva pamatpazīmēm un papildpazīmēm sk.: Krastiņš U., Liholaja V., Niedre A. 2008, 78.-80. lpp.

5 Latvijas Vēstnesis, 28.06.2019., Nr. 129.
} 


\section{Personas apzināšanās līmenis attiecībā pret līdzekḷu noziedzīgo izcelsmi}

Tā kā personas psihiskā attieksme pret apstākli, ka legalizētie līdzekḷi iegūti noziedzīgi, var izpausties vairākos veidos - kā zināšana, apzināšanās vai apzināta piel̦aušana -, jānorāda uz šo jēdzienu krimināltiesību teorijā izstrādātajām nostādnēm.

Zināšana ir nepārprotama apzināšanās par kāda apstākḷa esamību - konkrēti, ka līdzekḷi, kas tiek legalizēti, ir iegūti noziedzīgi. Darbības vai bezdarbības apzināšanās (plašākā izpratnē) nozīmē to, ka persona noziedzīga nodarījuma izdarīšanas laikā, balstoties uz dzīves pieredzi, izglītību, profesionālajām iemaņām, intelektuālo līmeni un citām īpašibām, saprot sava nodarījuma faktiskos apstākḷus un to, ka viṇa rīcība apdraud citas personas likumīgās intereses vai tām nodara kaitējumu. Apzināts piel̦āvums (apzināšanās šaurākā izpratnē) nozīmē to, ka konkrēts apstāklis saistībā ar personas reālu rīcību noteiktos apstākḷos ir bijis iespējams, ka tas ir varbūtējs. ${ }^{6}$ Attiecībā uz piel̦āvumu jāatzīmē, ka krimināltiesībās piel̦āvums kā personas psihiska darbība nav abstrakts jēdziens. Piẹ̦āvuma saturs atklājas personas tīšas darbības un bezdarbības vai kaitīgo seku rašanās apstākḷos ārējā (reālajā) pasaulē, tāpēc pieḷāvuma reālā izpausme, tāpat kā citos kāda apstākḷa apzināšanās gadījumos (zināšana, apzināšanās plašākā nozīmē), l̦auj secināt par piel̦āvumu kā personas psihiskās darbības saturu un apjomu.

Tajā pašā laikā, novērtējot pirmstiesas procesā un tiesā iegūtos pierādījumus, ir svarīgi ievērot, ka noteikta apstākḷa pieḷaušanu kā personas psihisko darbību un kā cilvēka domāšanas rezultāta konstatējumu nedrīkst balstīt vienīgi uz log̣iskiem vai subjektīviem pieṇēmumiem. Pieṇēmumi, kas nebalstās uz reāliem faktiskiem apstākliem, var novest pie subjektīvās pieskaitāmības, kas nozīmē noziedzīga nodarījuma izdarīšanas inkriminēšanu bez vainas. Tikai rūpīgi un vispusīgi noskaidrojot un kopsakarībā neitrāli novērtējot nodarījuma faktiskos apstākḷus, ir iespējams noskaidrot nodarījumu izdarījušās personas patieso psihisko attieksmi piẹ̦āvuma veidā attiecībā pret reāli pastāvošu apstākli, tas ir, ka ar konkrētajām darbībām līdzekḷi ir iegūti noziedzīgi.

Šajā personas psihiskās darbības izvērtēšanas procesā daudz var palīdzēt jau esošās tiesu prakses apkopojumi un veidojusies judikatūra, kas atspoguḷota arī Krimināllikuma komentāros. ${ }^{7}$

\section{Nolūks kā personas psihiskās attieksmes pret nodarījumu papildpazīme}

Viens no KL 195. pantā paredzētā nozieguma subjektīvās puses aspektiem ir nolūks, kura saistības izpratne ar noziedzīgi iegūtu līdzekḷu legalizāciju kā

6 Krastiņš U., Liholaja V. 2018, 61.-62. lpp.; Krastiņš U. Krimināltiesību teorija un prakse. Viedokḷi. Problēmas. Risinājumi (2015-2017). Rīga: Tiesu namu aǵentūra, 2018, 100. lpp.; Krastiņš U. Novitātes Krimināllikuma 195. un 314. panta regulējumā. Jurista Vārds, 28.11.2017., Nr. 49; Krastiņš U. Tieša nodoma tvērums krimināltiesībās. Krimināllikuma 9. panta otrās daḷas paplašināts komentārs ar teorētiskām nostādnēm. Rīga: Tiesu namu aǵentūra, 2017, 25.-26. lpp.

7 Krastiņš U., Liholaja V., Hamkova D. Krimināllikuma komentāri. Trešā daḷa (XVIII-XXV nodaḷa). 2. papild. izd. Rīga: Tiesu namu aǵentūra, 2019, 126. lpp. 
kriminālsodāmu nodarījumu ir visvairāk apspēlēta dažādos pārspriedumos gan krimināltiesību teorijā, gan praktiskajos risinājumos.

Runa ir par Likuma 1. panta pirmās daḷas 1. punktā iekḷauto KL 195. pantā paredzētā nozieguma subjektīvās puses papildpazīmi - nolūku. Šajā punktā ir paredzēts, ka legalizācijas objektīvās puses darbības - noziedzīgi iegūtu lìdzekḷu pārvēršana citās vērtībās, to atrašanās vietas vai piederības mainīšana - tiek veiktas nolūkā slēpt vai maskēt līdzekḷu noziedzīgo izcelsmi vai palīdzēt citai personai, kura iesaistìta noziedzīga nodarījuma izdarī̌anā, izvairīties no juridiskās atbildības. Turpretī šà panta pirmās daḷas 2. punktā minētās darbības noziedzīgi iegūtu līdzekḷu patiesā rakstura, izcelsmes, atrašanās vietas, izvietojuma, kustības, piederības slēpšana vai maskēšana - ar iepriekšminēto nolūku netiek saistitas.

Tāds atšksirīgs nolūka traktējums gan netiek uzsvērts Krimināllikuma komentāru pēdējos izdevumos, ${ }^{8}$ bet par to îpaši norādīts Augstākās tiesas Senāta Krimināllietu departamenta senatoru kopsapulces 2019. gada 19. jūnija lēmuma lemjošās daḷas 1. punktā. ${ }^{9}$ Šajā aspektā ir vērts atzīmēt, ka nolūka atšḳirīgais skaidrojums attiecībā uz noziedzīgi iegūtu līdzekḷu legalizāciju lielā mērā skaidrojams ar likuma izmaiṇām samērā îsā laika posmā.

Saeimas 2008. gada 17. jūlija likuma - Noziedzīgi iegūtu līdzekḷu legalizācijas un terorisma finansēšanas novēršanas likuma - 5. panta pirmajā daḷā visos trīs punktos minētās darbības bija saistītas ar nolūku: slēpt vai maskēt līdzekḷu noziedzīgo izcelsmi vai palīdzēt citai personai, kura iesaistīta noziedzīga nodarījuma izdarīšanā, izvairīties no juridiskās atbildības. ${ }^{10}$ Ar Saeimas 2011. gada 31. marta grozījumiem ${ }^{11}$ iepriekšminētā likuma 5. pantā norāde uz legalizēšanas nolūku tiek attiecināta tikai uz darbībām, kas minētas šà panta pirmās daḷas 1. punktā.

Pèc mana ieskata îpaša nolūka atšḳirīgā sasaiste tikai ar daḷu no legalizēšanas objektīivajām darbībām, kas minētas Likuma 5. panta pirmās daḷas 1. un 2. punktā, teorētiski nav attaisnojamas, bet praksē rada neattaisnojamu noziedzīgi iegūtu līdzekḷu legalizācijas izpratni jautājumā par KL 195. pantā paredzētā nozieguma subjektivo pusi.

Tam, ka likumdevējs atteicies no īpaša nolūka sasaistes ar Likuma 5. panta pirmās daļas 3. punktā paredzētajām darbībām, nosakot atbildību par citas personas noziedzīgi iegūtu lìdzekḷu iegūšanu īpašumā, valdījumā vai lietojumā vai to realizēšanu, saistot šīs darbības tikai ar apzināšanās nosacijumu, ka šie līdzekḷi ir noziedzīgi iegūti (Saeimas 2017. gada 22. jūnija grozījumu redakcijā) ${ }^{12}$ ir teorētiski attaisnojams risinājums.

Likuma 5. panta pirmās dal̦as 3. punktā paredzētās darbības ir piesaistības citas personas izdarītam noziedzīgam nodarījumam gadījumos, kas nav lïdzdalỉba KL 20. panta izpratnē, jo nav iepriekš apsolītas, tomēr likumdevējs tās atzinis par kriminālā kārtā sodāmām. ${ }^{13}$

\footnotetext{
${ }^{8}$ Krastiņš U., Liholaja V., Hamkova D. 2019, 129. lpp.

9 Tiesnešu kopsapulču lēmumi. Krimināllietu departaments. Pieejams: http://www.at.gov.lv/lv/ judikatura/tiesnesu-kopsapulcu-lemumi/kriminallietu-departaments

${ }^{10}$ Latvijas Vēstnesis, 30.07.2008., Nr. 116.

11 Latvijas Vēstnesis, 15.04.2011., Nr. 60.

12 Latvijas Vēstnesis, 05.07.2017., Nr. 132.

13 Piesaistība noziedzīgam nodarījumam ir tāda tī̌̌a darbība vai bezdarbība, kas saistīta ar citas personas izdarītu noziedzīgu nodarījumu, bet tā nav to izraisỉjusi vai palīdzējusi nodarījumu izdarìt.
} 
Tātad tas ir patstāvīgs noziedzīgs nodarījums un nav saistāms ar Likumā paredzēto īpašo nolūku. Lìdzdalības nosacījumi attiecas arī uz legalizēšanas nolūka daḷu, kas formulēta kā "[..] palīdzēt citai personai, kura iesaistīta noziedzīga nodarījuma izdarī̌̌anā, izvairīties no juridiskās atbildības” (Likuma 5. panta pirmās daḷas 1. punkts). Tas nolūka formulējumā ierakstīts lieki. Ja konkrētās darbības iepriekš apsolìtas, tā ir līdzdalība, bet, ja tāda apsolijuma nav, tad tā ir piesaistība citas personas izdarītam noziedzìgam nodarījumam.

Turpmāk par nolūku, kas formulēts kā "[..] slēpt vai maskēt līdzekḷu noziedzīgo izcelsmi [..]”. Uzskatu - ja šis nolūks īpaši iekḷaujams KL 195. pantā paredzētā nozieguma subjektīvajā pusē kā papildpazìme, tad tas attiecināms uz Likuma 5. panta pirmās daḷas visām 1. un 2. punktā norādìtajām darbībām, jo noziedzīgi iegūto līdzekḷu legalizēšanas objektīvās darbības pēc to izpausmes ir līdzìgas un atbilst KL 195. pantā paredzētā nozieguma - noziedzīgi iegūtu līdzekḷu legalizācijas - jēgai, tāpēc likumā noteiktajam nolūkam ir jābūt lìdzīgam. Taču tajā pašā sakarībā jānorāda, ka iepriekš minētais nolūks, kaut arī ir saistīts ar legalizācijas procesu, neattiecas uz tām darbībām, kas norādìtas Likuma 5. panta pirmās daḷas 1. un 2. punktā, tas ir, uz darbībām, ar kuru palīdzību noziedzīgi iegūtie līdzekḷi faktiski (objektīvi) tiek legalizēti.

Krimināltiesībās ar nolūku saprot personas psihisko darbību, kas personai rada vēlmi sasniegt noteiktu mērḳi reālajā dzīvē, nolūks aktivizē personas gribu uz izvēlētā mērḳa sasniegšanu, tas ir, izdarìt kādu prettiesisku darbību vai sasniegt konkrētu noziedzīgu rezultātu. ${ }^{14}$ Ikviens noziedzīgs nodarījums, kas tiek izdarìts ar tiešu nodomu, un tāds ir arī KL 195. pantā paredzētais noziegums, tiek realizēts nolūkā sasniegt noteiktu rezultātu, konkrētajā gadījumā - legalizēt noziedzīgi iegūtus līdzekḷus. Saistībā ar noziedzīga nodarījuma sastāvu nolūks var būt paredzēts kā subjektīvās puses obligāta pazīme. Tad tas tiek iekl̦auts konkrētā noziedzīgā nodarījuma subjektīvās puses pazīmju skaitā un ir pierādāms. Citos gadījumos nolūkam var būt nozìme, lai konstatētu, ka noziedzìgais nodarījums ir izdarìts ar tiešu nodomu.

Krimināllikuma 195. pantā paredzētais noziegums izpaužas kā noziedzīgi iegūtu līdzekḷu legalizācija un ir pabeigts ar Likuma 5. panta pirmajā daḷā paredzēto darbību izdarīšanu (formāls sastāvs). Kas attiecas uz legalizēšanas nolūku, tad tādas darbības ir: noziedzīgi iegūtu līdzekḷu pārvēršana citās vērtībās, to atrašanās vietas vai piederības mainīšana (1. punkts), noziedzīgi iegūtu līdzekḷu patiesā rakstura, izcelsmes, atrašanās vietas, izvietojuma, kustības, piederības slēpšana vai maskēšana (2. punkts). Par 3. punktā minēto darbību juridisko izvērtējumu jau runāts iepriekš.

\section{Nolūka jēga saistībā ar Krimināllikuma 195. pantā paredzētā nozieguma objektīvajām līdzekḷu legalizēšanas izpausmēm}

Pamatjautājums ir par to, kāds ir personas patiesais nolūks gadījumos, kad tiek izdarīta noziedzīgi iegūtu līdzekḷu legalizēšana. Visu Likuma 5. panta pirmās daḷas 1. un 2. punktā paredzēto darbību aptverošais nolūks ir ietverts

\footnotetext{
14 Vairāk sk.: Krastiņš U. Nolūka (mērḳa) saistība ar vainu krimināltiesībās. Grām.: Centrālās un Austrumeiropas juridiskās tradīcijas un juridiskās identitātes jautājumi. Latvijas Universitātes 76. starptautiskās zinātniskās konferences rakstu krājums. Rīga: LU Akadēmiskais apgāds, 2018, 243.-249. lpp.
} 
KL 195. pantā formulētā noziedzīgā nodarījuma objektīvās puses apzīmējumā noziedzīgi iegūtu lìdzekḷu legalizēšana.

Ko nozīmē vārds "legalizācija"? Šis vārds cēlies no latīṇu valodas vārda legalis ar nozìmi 'likumìgs'. 15

Krimināllikuma 195. pantā paredzētais noziegums ir formāla sastāva nodarījums, jo tas skaitās pabeigts ar brīdi, kad vainīgais ir izdarījis tādas darbības, kas paredzētas Likuma 5. panta pirmajā dal̦ā.

Apzīmējot KL 195. pantā paredzēto noziegumu ar vārdu "legalizēšana", likumdevējs ir norādijis uz pabeigtu personas darbības procesu, kas noslēdzies ar tādas konkrētas darbības izdarī̌̌anu, kuras norādītas Likuma 5. panta pirmajā daḷā: noziedzīgi iegūtu līdzekḷu pārvēršana citās vērtībās, to atrašanās vietas vai piederības maiṇa (1. punkts), noziedzīgi iegūtu līdzekḷu patiesā rakstura, izcelsmes, atrašanās vietas, izvietošanas vietas, izvietojuma, kustības, piederības slēpšana vai maskēšana (2. punkts).

Te nu esam nonākuši pie jautājuma, kāpēc likumdevējs vienu grupu darbību saista ar īpašu nolūku: slēpt vai maskēt legalizēto līdzekḷu noziedzīgo izcelsmi (1. punkts), bet attiecībā uz otras grupas darbībām (2. punkts) tādas prasības nav?

Teorētisku skaidrojumu tādam risinājumam neesmu atradis. Konsekventa Likuma 5. panta pirmās daḷas 1. punktā iekḷautā tur minēto darbību nolūka tekstuāla atkārtošana atbildi nedod. Likuma 5. panta pirmās daḷas abos punktos norādītās darbības pēc savas faktiskās un juridiskās būtības neatšķiras, ja runa ir par noziedzīgi iegūtu līdzekḷu legalizēšanu, jo darbību raksturs norāda uz viena un tā paša rezultāta sasniegšanu, tāpēc personas psihiskai attieksmei pret vēlamo rezultātu, kas krimināltiesībās tiek nosaukta par nolūku, būtu jābūt vienādai.

Ar to gribu teikt, ka patiesais legalizēšanas nolūks būtu jāattiecina uz visām tām darbībām, kas norādītas Likuma pirmās daḷas 1. un 2. punktā. Tad kāds ir noziedzīgi iegūtu līdzekḷu legalizēšanas nolūks? Kaut arī Likumā tas nav pateikts un teorētiskajās izstrādēs ir apiets, noziedzīgi iegūtu līdzekḷu legalizēšanas nolūks ir izkristalizējies tiesu praksē. Par šì nolūka saturu ir teikts Augstākās tiesas 2013. gada tiesu prakses apkopojuma "Tiesu prakse lietās par noziedzīgi iegūtu līdzekḷu legalizēšanu un par izvairī̌sanos no nodokḷu maksāšanas” rezumējumā. ${ }^{16}$

Iepriekšminētajā tiesu prakses apkopojumā ir sagrupētas tiesu nolēmumos konstatētās faktiskās darbības, kas norāda uz legalizēšanas objektīvo izpausmi, un ir izteikts secinājums, ka šìs personas darbības, kas ārēji atbilst likumīgām, ir izdarìtas nolūkā radīt ar noziedzīgo nodarījumu nesaistītajām personām šķietamību par darījumu un tajā izmantoto līdzekḷu legalitāti.

Manuprāt, Augstākās tiesas prakses apkopojumā ir pietiekami precīzi izteikts KL 195. pantā paredzètā nozieguma - noziedzīgi iegūtu lìdzekḷu legalizēšanas - nolūks.

No iepriekš teiktā var izdarìt secinājumu, ka Likuma 5. panta pirmās daḷas 1. punktā ieklautā norāde uz ìpašu nolūku, pirmkārt, sašaurina KL 195. pantā

${ }^{15}$ Fr. legalisation < lat. legalis, bet latviešu valodā - 'nelegālu darbību atzīt par likumīgu'. Svešvārdu vārdnīca. J. Baldunčika red. Rīga: Jumava, 1999, 428. lpp.

16 Tiesu prakses apkopojumi. Krimināltiesības. Pieejams: http://at.gov.lv./lv/judikatura/tiesu-praksesapkopojumi/kriminaltiesibas/ 
paredzētā nozieguma nolūka jēgu, tāpēc tā no Likuma 5. panta būtu izslēdzama, un, otrkārt, tāds nolūks attiecas tikai uz noziedzīgi iegūto līdzekḷu noziedzìgo izcelsmi, tāpēc ir tikai viens no noziedzīgi iegūtu līdzekḷu legalizēšanas nosacìjumiem. Pati noziedzīgi iegūtu līdzekḷu legalizēšana kā darbība seko pēc tam, kad persona lìdzekl̦us jau ir noziedzīgi ieguvusi.

Ja persona pati lìdzekḷus ieguvusi noziedzīgi un tos pēc tam tikai glabā, bet neveic tādas darbības, kas paredzētas Likuma 5. panta pirmās dalas 1. vai 2. punktā, tad nav notikusi noziedzīgi iegūtu līdzekl̦u legalizēšana KL 195. panta izpratnē. Tādi līdzekḷi ir konfiscējami kā noziedzīgi iegūti Krimināllikumā vai Kriminālprocesa likumā noteiktajā kārtībā.

Vērtējot to, vai tās darbības, kas paredzētas Likuma 5. panta pirmās daḷas 1. un 2. punktā, ir izdarītas nolūkā radìt šķietamību (ticamību) par darījumu un tajā izmantoto līdzekḷu legalitāti (likumību), ir pierādiš̌anas priekšmets. Legalizēšanas nolūka pierādīšanu var atvieglot darbību faktiskā izpausme, kā arī tas apstāklis, ka līdzekḷi ir iegūti nelikumīgi, ko legalizētājs apzinās, tāpēc šādu lìdzekḷu legalizēšana Likuma 5. panta pirmās daḷas 1. un 2. punktā paredzētajā veidā jau objektīvi liecina par iepriekš minēto nolūku. Tāda nostādne izriet no noziedzīgi iegūtu līdzekḷu legalizācijas novēršanas mērḳa satura - noziedzīgi iegūtiem līdzekḷiem ir jānonāk valsts ìpašumā. Teiktais neizslēdz, ka, piemēram, atsavinot vai citādā veidā nododot noziedzīgi iegūtus līdzekḷus citām personām, nevar būt vēl kāda blakus interese, tajā skaitā nemateriāls labums, piemēram, dāvinājuma gadījumā panākt draudzīgu vai labvēlīgu attieksmi pret dāvinātāju. Taču tas neizslēdz legalizēšanas nolūku, kas izpaužas faktiskajās darbībās, jo līdzekḷi ir iegūti noziedzīgi, ko vainīgais apzinās.

\section{Kopsavilkums}

1. Noziegums, kas paredzēts KL 195. pantā - noziedzīgi iegūtu līdzekḷu legalizēšana -, tiek izdarīts ar tiešu nodomu, jo noziegums ir pabeigts ar legalizējošo darbību izdarǐšanu konkrētā nolūkā.

2. Nolūks ir noziedzīgu nodarījumu izdarījušās personas psihiskā darbība, kas reālajā dzìvē tiek realizēta kā viṇas gribas virzìta rīcība uz nolūkā ietvertās darbības (formālos sastāvos; tāds ir KL 195. pantā paredzētais noziegums) izdarīšanu vai kaitīgo seku nodarī̌̌anu (materiālos sastāvos).

3. Nozieguma, kas paredzēts KL 195. pantā, nolūks ir radìt ar noziegumu nesaistītajām personām škicietamību (ticamību) par nodarìjumu un tajā izmantoto līdzekḷu legalitāti (likumību), izdarot darbības, kas paredzētas Noziedzīgi iegūtu līdzekḷu legalizācijas un terorisma un proliferācijas finansēšanas novēršanas likuma 5. panta pirmās daḷas 1. un 2. punktā.

4. Tà kā legalizētie lìdzekḷi ir iegūti noziedzīgi, ko vainīgais apzinās, tad to realizācija un Likuma 5. panta pirmās dal̦as 1. un 2. punktā norādīto darbību izdarī̌ana jau liecina par legalizēšanas nolūku.

5. Iepriekš formulētais noziedzīgi iegūtu līdzekḷ legalizēšanas nolūks vienādā mērā attiecas kā uz Likuma 5. panta pirmās daḷas 1. punktā, tā 2. punktā norādītajām darbībām.

6. Likuma 5. panta pirmās daḷas 1. punktā norādītais nolūks - slēpt vai maskēt līdzekḷu noziedzìgo izcelsmi - neatklāj legalizēšanas nolūka saturu un jēgu, 
jo attiecas vienīgi uz līdzekḷu noziedzīgās izcelsmes faktu, bet ne uz lìdzekḷus legalizējošajām darbībām, tāpēc no likuma izslēdzams.

7. Ja persona līdzekḷus ieguvusi noziedzīgā cel̦ā, piemēram, izdarījusi mantiska rakstura noziedzīgu nodarījumu vai citādi, un tos paturējusi (glabājusi), nav izdarìts noziegums, kas paredzēts KL 195. pantā. Tādi noziedzīgi iegūti līdzekḷi ir konfiscējami Krimināllikuma vai Kriminālprocesa likumā noteiktajā kārtībā kā noziedzīgi iegūti. 